\title{
The reception of Hume in Romance Languages: French and Portuguese ${ }^{\prime}$
}

\author{
L. Hollanda ${ }^{2}$ \\ University of São Paulo
}

\begin{abstract}
Indeed, the most of myths about Hume's philosophy rest on the precarious term empiricist. J. P. Monteiro, impeaching this conception, had proposed deep revisions in interpretations of Hume's philosophy, such as the rebuttal of any Humean cognitive associationism. Gilles Deleuze, on the other hand, had stated that causal inferences play a crucial role for the constitution of human nature in Hume's thought. In line with Deleuze, but far from Monteiro's interpretation, Gerard Lebrun depicted Hume as a free spirit and the most ingenuous sceptic. This text, which strictly handled with Portuguese and French commentators, is the first one of a series of texts that I intend to release in order to spread into English key commentaries about Hume's philosophy published in Romance languages. This paper, as well as some other ones that are coming, aimed at shedding light on the manner as Hume's philosophy was undertaken in Romance languages. In view of this, it was taken - as this text main base - the aforementioned Romance commentators, as I named the group of Hume's commentators who had written in Romance languages.
\end{abstract}

Keywords: Romance languages. Hume. Scepticism.

\footnotetext{
${ }^{1}$ In the next text, my intention is dealing with Italian and Spanish commentators. This essay, which strictly treats with commentaries in Portuguese and French, is the first one of a series by which I intend to spread into English great works on Hume's philosophy published in Romance languages.

2 (DORCID: 0000-0002-2210-7955. Research Student of Philosophy, grant \#16/20766-6, São Paulo Research Foundation (FAPESP). E-mail: leo@usp.br
} 
In Romance languages, such as French, Italian, Portuguese and Spanish, there is a long and interesting tradition of commentaries about Hume's philosophy. Despite being vast and noteworthy for contributing to figure out solutions to typical Humean problems, the reach of such commentaries is undoubtedly short due to language barriers. For example, J. P. Monteiro - by calling out the label of sceptic-empiricist on Hume - had proposed deep revisions in many "standard" interpretations of Hume's philosophy, such as the rebuttal of any Humean cognitive associationism; the inversion of a psychological associationism in the cognitive process for a rational inference, and what he believed being the mistake of ascribing a general induction to Hume, given that he, according to Monteiro, just dealt with causal inference. Gilles Deleuze, on the other hand, stated that causal inferences play a crucial role for the constitution of human nature in Hume's thought. According to Deleuze, Hume's philosophy is essentially an expression of the dominium of sentiment or feeling over mankind's lives. In line with Deleuze, but far away from Monteiro's interpretation, Gerard Lebrun depicted Hume as a free spirit and the most ingenuous sceptic.

This text, which strictly coped with Portuguese and French commentaries, is the first one of a series that I intend to release in order to spread into English key commentaries about Hume's philosophy, which were published in Romance languages. Along this essay, I am going to bring up commentators from Portuguese and French languages, namely: J. P. Monteiro, Gerard Lebrun and Gilles Deleuze. As well as other texts that are coming, this essay aimed at shedding light on the manner as Hume's philosophy was undertaken in Romance language speaking countries. Still

\section{Blucher}




\section{Hollanda}

on the approach of this text, it was taken as primary base the aforementioned Romance commentators (I have used this term along the essay to name the group of Hume's commentators in Romance languages). Firstly, it is discussed some of J.P. Monteiro's commentaries; secondly, it is brought up Gerard Lebrun's interpretation and, at the end, the widely known Gilles Deleuze.

\section{I) J.P. Monteiro:}

One of the largest oeuvres written in Portuguese about Hume's thought belongs to Joao Paulo Monteiro, who dedicated the most part of his works to Hume. Yet Monteiro's labour grandeur is not only justified by his workload. Along with this, Monteiro's major contribution consist in the innovative interpretation introduced by him to the Humean philosophy. Such originality was mentioned by himself in Hume and Epistemology3: "I proposed radical changes to the comprehension of Hume" (MONTEIRO, 2009, p. 7). Furthermore, the Brazilian edition of Hume and Epistemology was released after deep changes in comparison with the Portuguese one, which was published more than twenty years earlier. By the way, these changes were commented by Monteiro (2009, p. 7): "passed more than twenty years, it is natural that there is more to change than some mere typographic mistakes (...). Seemingly, may there be the necessity of proceeding alterations in commentator's interpretation of 'his' philosopher". Monteiro's reading about what just then he came to recognise as "an old myth about Hume's philosophy" (id., 2009, p.9) is,

\footnotetext{
${ }^{3}$ The original title is Hume e a Epistemologia, which all quotations mentioned later on were translated into English by me, the same is truth of Novos Estudos Humeanos (here quoted as Humean New Studies) and Teoria, Retórica, Ideologia (here translated as Theory, Rhetoric, Ideology). For stylistic sense I have preferred to translate Monteiro's titles into English along the body of this text, seemingly the quotations from his books - hereby mentioned - were thoroughly translated. The exception is in bibliography, where titles were not translated.
} 


\section{The reception of Hume in Romance Languages: French and Portuguese}

indeed, the deepest change that comes out when the Brazilian edition is compared to the Portuguese one. According to Monteiro, such a "myth" was originated from the concept of induction ascribed to Hume by Russell.

In the same work, Monteiro (op. cit., p. 12) admits he made a "large number of changes on the Portuguese edition texts" about the notion of induction, this one that only later he noticed as a "problem" in Russell's interpretation, which he and the tradition "followed without realising". Moreover, according to him, the term induction itself is problematic to be assigned to Hume "in the sense it does not appear even once in his works meaning causal inference". Therefore, Monteiro argued "Hume had never undertaken such inductive reasoning trouble itself" (op. cit., p. 12). Considering this, he builds lines of an argument that aims at deconstructing that famous Russell's thesis. Furthermore, this abovementioned issue with Russell's interpretation was earlier treated by Monteiro in a book entitled Humean New Studies (2003), which was released shortly after the publication of his paper Russell and Humean Inferences (2001), whereby he puts forward, for the first time in his writings, the argument against the Russellian reading.

Besides, in Humean New Studies (henceforth NHE) he shows "the misconceptions generated" from the attribution of "a sceptical theory of induction" to Hume; in his view, the Scottish philosopher "dealt with causal inference only and not with induction in general" (Id. Ibid., p. 11). Yet the attribution of such a theory to Hume, which Monteiro strongly disagrees with, has a notorious precursor according to him: Bertrand Russell. Nevertheless, even though Monteiro makes clear his opposition to Russell immediately in NHE preface, the same did not happen throughout many decades, when he shared Russell's opinion without a doubt. Furthermore, as it

\section{Blucher}




\section{Hollanda}

was stated in another text by me (HOLLANDA, 2017), NHE is Monteiro's first book - and the last one - released after his final interpretative turn on the Humean philosophy. Certainly due to the great influence of this turn, Monteiro decided to launch - with innumerable ${ }^{4}$ changes - the second edition of his most famous book, i.e. Hume and Epistemology. As even the author acknowledges (op. cit., p.14), by comparing the 1984 version of this book with the 2009 edition, there is no essay which Monteiro had prevent himself of making changes in, each and every single one motivated by what I have called his last interpretative turn ${ }^{5}$.

Although such changes in Monteiro's thought, motivated by that turn, had already appeared since the late nineties in some articles, they were compiled just in 2003 by means of NHE. Nonetheless, Monteiro's reasons for those changes had just come to light six years later, along the preface to the second edition ${ }^{6}$ of Hume and Epistemology (2009). Specifically, regarding the concept of induction, which in NHE is the theme of chapter five, Monteiro begins by clarifying that the change of perspective on such a concept leaded him "to make numerous changes". The thesis held by Monteiro $(2009$, p. 12) is based on the argument that to apply the term induction to speak about Hume's philosophy is not only problematic "inasmuch as it does not appear along his works as a synonym of 'causal inference', but also because Hume, eventually, had never dealt with inductive reasoning in general, but only with causal reasoning". He argues further that although

\footnotetext{
${ }^{4}$ In this regard, J.P. Monteiro (2009, p. 14) writes: "I did not consider useful to indicate these changes that I had to make, as this would result in a too tedious reading given the large number of alterations".

${ }^{5}$ From the Portuguese to the Brazilian edition, even the titles of his essays have not passed unmodified. To be more specific, the chapter number seven - the same in both editions - went through more changes than any other one. In this case, even its title did not escape from the modifications carried out by Monteiro. In 1984, it was entitled Induction and Natural Selection, but in the Brazilian edition, in 2009, it was called Causality and Natural Selection.

${ }^{6}$ It was released only in Brazil.
} 
"causal inference may be regarded as a form of inductive inference" it does not mean that Hume took into account the concept of induction in his epistemology (Id. Ibid., pp. 12-13).

In order to understand Monteiro's conceptual distinction, the concept of induction semantic-field has to be appreciated broader. Monteiro had stressed that it is necessary to realise a typified interaction in what he called "inductive field". Consequently, he argues that although a causal inference can be regarded as an inductive inference, not all inductive inference can be considered a causal inference. Along this lines, in the inference "all crows are black" the reasoning "left the 'sample' of a natural phenomenon to conclude that its characteristics are common to all members of this class of phenomena" (Id. Ibid., p. 12). From this, it is possible specifically understand what Monteiro meant by "inductive reasoning in general", which Hume would have never dealt with, since he would have been restricted to causal inference. However, it can be argued that Hume falls back on inferences such as "all crows are black". Notwithstanding, Monteiro (op. cit., p. 13) argued that all instances in which examples of the latter sort are found in Humean philosophy, they are not taken as inductive inferences but as "discoveries from the sensible qualities of objects". In his own words: "I sustain that Hume never speaks of inductive inferences, in any fully comprehensible sense, simply because the very concept of induction is not taken into account in his epistemology at all" (Id. Ibid., p. 13). Briefly, the major Monteiro's arguments along his works on Hume's Philosophy could be outlined as:

I) the rebuttal of any Humean cognitive associationism;

II) the critic and refuse of any psychological assumption concerning the notions of habit and custom; 


\section{Hollanda}

III) the exchange of psychological associationism for rational inference in cognitive process;

IV) the defence that Hume had not written about general induction but upon causal inference only;

V) the anti-empiricist aspect of human nature science and its unobservable principles;

VI) the unevenness of Humean rhetoric, which revels a double level in Hume discourse: a rhetoric and a theoretical.

\section{II) Gerard Lebrun:}

Furthermore, still on Monteiro's interpretation, I have just brought up his arguments against the possibility of a rational associationism and a sceptical theory of induction in Hume's thought. However, in contrast to Monteiro's view, Gerard Lebrun ${ }^{7}$ (2011 [1976], p. 12) describes Hume, in one of his most shrewd texts ${ }^{8}$ about Hume's philosophy, as "the most ingenuous sceptic". It works to evoke a range of differences between Lebrun's and Monteiro's readings; by the way, there are few possibilities of approximating these two interpreters. Having cleared this important dissent, I would like to start introducing Lebrun by probing into what he called a new definition of necessity, which is ascribed to Hume in The Charing-cross sally ${ }^{9}$, his most important essay about

\footnotetext{
${ }^{7}$ A curiosity about Lebrun is that many of his writings are available as in French as in Portuguese. His texts written in Portuguese are an outcome of the time he spent in Brazil teaching at University of São Paulo.

${ }^{8}$ And also one of the shortest, the text, which brings up witty comparisons between Hume and Kant, has no more than 15 paragraphs.

${ }^{9}$ It is my free translation for Lebrun's text entitled La Boutade de Charing-Cross (which was never translated into English).
} 
Hume's thought. In spite of Lebrun had never been a "Hume scholar", his contributions to the studies of Hume's philosophy are, undoubtedly, one of the best available in French. Hume's motto found out by Lebrun to start his commentary is in Enquiries Concerning Human Understanding, section VIII, part I (HUME, 2010, p. 91):

A man who at noon leaves his purse full of gold on the pavement at CharingCross, may as well expect that it will fly away like a feather, as that he will find it untouched an hour after. Above one half of human reasoning contain inferences of a similar nature, attended with more or less degrees of certainty proportioned to our experience of the usual conduct of mankind in such particular situations.

In view of this Hume's statement, Lebrun puts forwards his investigation by pointing out the moral and physic necessity is at stake in such an affirmation. According to him, Hume's goal in that quotation consists in coming out that "the elements behaviour constancy is neither stronger nor lesser strong than human behaviour". So as to "the confidence in the nature laws is no more than a fair enough expectancy" (LEBRUN, 1978, p. 145). In this lines, according to him, what Hume puts on equal terms is the aforementioned two sorts of necessity. However, Lebrun also had explained that, when Hume matches this two forms of necessity, he is not defending both are suchlike. Instead, he is enlightening that we are conduced to "two consecutive interpretations of free action, both wrong" for the sake of their identification, which are promoted by imagination. Thereby, stepping up his main argument in the essay, Lebrun contends that, according to the Humean philosophy, these misinterpretations about free action are responsible for "the idea of freedom forged by men" (Id. Ibid., p. 146). Thence, he tries to explain what consist of these two

\section{Blucher}




\section{Hollanda}

major misinterpretations by assimilating both necessities. According to Lebrun, therefore, it is possible to sum up from Hume's thought (Id. Ibid., pp. 146-147):

I) The driven power of will on body: the command carried out by will upon the body is accountable for arising up the idea of power, which goes halves with external objects. Thus, such power, which itself is just a human contrivance, is so an "illegitimate paradigm" that leads to idea of freedom. For Lebrun, regarding the Humean philosophy, "we have not got even the right to affirm any power of moving our limbs; we just know our will can drive some animal spirits" ${ }^{\prime 10}$. This power is fanciful for we are not able to discern more than a constant conjunction. We are up to realise our will can drive some animal spirits, but we are not capable of comprehending all its stances.

II) The illusory power of will turns into cause: ascribing a power of will to this process is surpassing our limited capacity and saying as true what is just a presumption. Yet it is astonishing not only for being a mistake, but also because we do not stop in it: we also exceed this illusory power and make up something else, now under the label of a concept, namely: cause. Therefore, according to Lebrun, "when we consider another aspect of free action we believe discover, amid the web of necessity, a spot of indifference or looseness". And then we are convinced that, from this looseness, our will exercises its power and, by means of it, comes out that thing we label "liberty", nay our free will".

\footnotetext{
${ }^{10}$ Lebrun justifies this by quoting Hume's Treatise of Human Nature, Book III, section II, § 9.

${ }^{11}$ In this case, Lebrun justifies this by citing Hume's Enquiries Concerning Human Understanding, section IV, part I, §24.
} 
Thereby, the idea of free will - whereby we thought the body is doomed to follow its leading - ensue from the deceitful notion of power. On this account, the belief in something like freedom comes on the scene from the conclusion that our will cannot be capitulated to any other power. Freedom is then understood on the ground that it represents a breaking out of some those intersections whereby the web of causes is constituted. This web of causes can also be caught on the ground of a necessity system or, in Lebrun's words, a "web of necessity". This means everything that rips off any those intersections on such a "web of necessity" is ready taken as a free deed. Furthermore, men do believe have the chance of scape from this web many times; they heck can offer a range of events in which they ripped off such a web by using their "power of will". This certainty is too deep-rooted that leads them, as any rational being, to turn mere constant conjunctions into necessity. Hence, they do not only are ensured they act freely some times; beyond they are assured being always able to do this either. Notwithstanding, as it is widely-known, for Hume "there be no such thing as Chance in the world" (EHU, Sec. VI, §46). Nevertheless, that certainty of holding a free will is such firmly embedded in mankind thought that, as stated by Lebrun, it plays a diffuser role in a large extent of crucial ideas. In this regard, as explained Lebrun, when the notion of necessary Connexion ${ }^{12}$ goes to the pieces, the idea of freedom cave in together.

Therefore, as Lebrun had argued, it is clear Hume had undertaken the so called necessity to enlighten that it tallies with mere constant conjunctions, as well all disputes over differences between both are merely rooted in words. Hence, the human sham of free will turned out in "the shattering of the real connection" (LEBRUN, 1978, p. 148). In view of this, according to Lebrun,

\footnotetext{
${ }^{12}$ Spelled and capitalised as in Hume's original writing.
} 


\section{Hollanda}

what Hume brought up then is that initially cited "new definition of necessity", this one which ends up reallocating the "power of will" and "free will" from a stance of truth to "an abusive presumption about experience" (Id. Ibid., p. 149). Consequently, necessity lose its status of truth and come into no more than a presumption held by the habitual amount of connected events that, in a calculation of probabilities, turns into certainty. Thus, according to Lebrun, necessity and contingence are no more apart, in Hume's philosophy they come to be connected. As two sides of same coin, they are different, but the same thing either.

\section{III) Gilles Deleuze:}

Nearer to his compatriot than to Monteiro's reading, Deleuze had written one of the most famous book in French about Hume's philosophy. It is by the development of his cognitive process analysis that Hume wants to explain the paradox between what reason shows as impossible, but we cannot stop believing it. For Hume, imagination acts through associations sorted as contiguity, resemblance, and causality; from them it concludes what goes beyond the limits of the experience. By one same token, imagination fantasises the independence and continuity of perceptions. Notwithstanding, as stated by Deleuze (2001, p. 69), fictions become a principle of human nature with the belief in bodies existence. This is to say, belief and habit turns a mere collection of ideas into a system that constitute the mind. Such a system is nothing but the "system of knowledge and the objects of knowledge" (Deleuze, 2001, 69). The imagination is creative, it relates different matters of fact and set up the needed conditions to awake the belief, which is fundamental for the knowledge coming up. Thus, for the sake of belief, fictions or fantasies become "principles of 
The reception of Hume in Romance Languages: French and Portuguese

nature". And the principles of association enable the mere collection of ideas to become a system of knowledge. Besides, the latter is only fully constituted as the belief in what was associated by the imagination. Therefore, such a system is a product of associative principles, mental faculties, and sentiment. While the world, on the other hand, as continuity and distinction, i.e. rationally, is fiction of the imagination. In this way, what Hume treats as fictitious "is the knowledge of the existence of bodies", whereas the belief is a crucial element in the constitution of knowledge system.

In this sense, in accord with Deleuze's viewpoint $(2001,72)$, there is a contradiction in Humean philosophy "between extension and reflection, imagination and reason", i.e. between "the senses and the understanding". Additionally, from my perspective, such a contradiction makes Hume see the solution to this problem as unattainable. This is because reason and passion, in spite of being opposed, cannot collapse each other. Thereby, Deleuze $(2001,73)$ stresses: for Hume's paradox "there is no choice to be made between one or the other principle, but between all or nothing, between contradiction or nothingness". Then, even after the most abstruse reflection, whereby it could be deduced the impossibility of a continuous existence, there would be no choice left to be made regarding the "suggestions of the imagination". Hence, instead of "referring nature to spirit, we must refer spirit to nature" (Deleuze, 2001, 74). In other words, instead of reflecting against the impositions of nature, it is necessary that the natural tendency ignores the "critique of reason", i.e. the philosophical reasoning, so that the constitution of practical knowledge occurs. At the end of Treatise's Book 1, it is possible to see Hume going deeper into this very contradiction. Then, in the meanwhile of such a contradiction, it is when one may find out the common sense impulse, which makes room to the establishment of science. Common sense must be caught on then as a synonym for scientific realism, i.e. observable and unobservable aspects of the world are

\section{Blucher}




\section{Hollanda}

described by science. And for Hume, once again according to Gilles Deleuze's $(2001,97)$ explanation, there is only science and life at the level of general rules and beliefs. In this regard, we go back to Monteiro (2009, p. 191), where he clarifies that "only nature inside us, and not philosophical reason, can restore trust in the knowledge".

By the way, it is important to discuss about the passivity or activity aspect of imagination in the course of knowledge process. This problem is dealt with by Gilles Deleuze in his same book, for whom imagination is, in Humean philosophy, a purely passive activity: "Imagination is neither a factor nor an agent, let alone a determinative determination; instead, it is a non-located place, that is, not yet fixed, is a determinable. Thence, according to Deleuze's perspective, it could be said that nothing is done by imagination, but everything is done in imagination. It would not be even a faculty for forming ideas: the production of ideas by imagination is only a reproduction of some impressions in the imagination" (Deleuze, 2001, p. 11). However, it is problematic to defend such passivity, especially when we are confronted with the following Hume's statement: "That action of the imagination, by which we consider the uninterrupted and invariable object, and that by which we reflect on the succession of related objects, are almost the same to the feeling, nor is there much more effort of thought required in the latter case than in the former" (T 1.4.6.6, italics mine). It is very true that Deleuze $(2001,11)$ admits the imagination "certainly has its activity", but for him "this very activity lacks constancy and uniformity, is fantasist and delusional, it is the movement of ideas, actions and reactions". I agree partly that Hume seems, occasionally, to ascribe passivity to the imagination in some extent, such as when he states that habit and experience act together upon the imagination (T 1.4.7.3). However, from my point of view, as Deleuze was inaccurate in 
supposing that imagination produces only fictions, as are inaccurate those ones who believe that imagination is fully active in Hume's philosophy.

Therefore, from my perspective, it is more likely possible that the most appropriate interpretation is to understand the imagination in Hume's thought as a creative and reproductive mechanism of human nature. Being more specific, imagination can be described as active for being the producer not only of fictions, but also of relations that lead to spark our beliefs. Although it is also passive, due to the extent that these produced relations can be possible just through the principles of association, which lead the imagination to make connections. Here my frontal divergence to Deleuze arises. When he says that nothing is done by the imagination - everything is done in the imagination - he means, as he clarifies later on, the principles of association are the real responsible for the connections of ideas. Thus they would use the imagination just to establish their own connections. Notwithstanding, Deleuze's approach sounds to me somewhat unfortunate, given that associative principles, in this case, seem metaphysical entities tacking over the imagination. The best interpretation for the principles of association, in my own conceit, is understanding them as tendencies, proper mechanisms in the performance of imagination. That is, the vivacity of the idea is always proportional "to the tendency to transition" of the idea by the imagination associative principles (T 1.3.12.13). 


\section{Hollanda}

\section{Bibliography:}

DELEUZE, Gilles. Empirisme et subjectivité. Paris: Presses Universitaires de France - PUF, 2001.

HOLLANDA, L. Fifteen years of a classic: New Humean Studies. Prometheus, v. 10, n. 23, MayAugust., 2017.

LEBRUN, Gérard. La Boutade de Charing Cross. Manuscrito, Campinas, v. 1, n. 2, pp. 65-84, 1978. Hume e a astúcia de Kant. In: TORRES FILH0, Rubens Rodrigues (ed.). Sobre Kant. São Paulo: lluminuras, 2011.

MONTEIRO, João Paulo. Novos Estudos Humeanos. São Paulo: Discurso Editorial, 2003. . Novos Estudos Humeanos. Lisboa: Imprensa Nacional/Casa da Moeda, 2003. . Hume e a Epistemologia. Lisboa: Imprensa Nacional/Casa da Moeda, 1984. . Hume e a Epistemologia. São Paulo: Editora UNESP, Discurso Editorial, 2009. 